\title{
UMA CRIANÇA CAÍDA DO CHÃO: contaminação e acoplamentos virais em currículos
}

A CHILD FELL ON THE FLOOR: contamination and viral coupling in the curriculum

\author{
Thiago Ranniery \\ Luan Carpes Barros Cassal ${ }^{2}$
}

\begin{abstract}
Resumo: Um acoplamento viral com HIV é uma composição que põe à prova os mecanismos da temporalidade da reprodução sexual e da relacionalidade social. Nesse artigo, nós analisamos o campo que cruza sexualidade e graus de ansiedade e pânico, explorando as dimensões da contaminação dentro um panorama mais amplo das políticas ecológicas. Para tanto, este texto é experimento narrativo a partir trajetórias de crianças vivendo com HIV nas escolas no qual argumentamos que a iminência de contaminação dos corpos nos currículos convida a pensar os entrelaçamentos entre vida e morte e vida e não-vida. Inspirados nos debates sobre biopoder, nós sugerimos que o vírus é uma figura de poder através da qual a materialização diferença é produzida como um erro metabólico do tempo da reprodução e da projeção do futuro. Desta forma, a experiência dessas crianças oferece um suplemento às considerações (bio)políticas dos debates ambientais e das políticas ecológicas. $\mathrm{O}$ agenciamento viral coloca enredamentos existentes nos currículos entre sexualidade e ecologia que tem recebido pouco crédito nos recentes debates sobre o Antropoceno. Esses laços complicam a imaginação ética da vida social ao expandir o corpo para além do humano. Eles ermitem abordar como e onde as disposições de poder dos currículos podem ser configuradas ao colabar os corpos como unidades separáveis em si mesmas e hermeticamente fechadas.
\end{abstract}

Palavras-chave: crianças com HIV; biopoder; ecologia queer; currículo.

\section{UMA INSTRUÇÃO PARA O/A LEITOR/A}

Este ensaio é uma crítica experimental. Trata-se de um esboço tentativo para desdobrar, do ponto de vista do pensamento curricular, uma agenda há muito testemunhada pelas ciências humanas e sociais, que afetam tanto objetos quanto métodos de investigação; algo que poderíamos nomear, com

\footnotetext{
${ }_{1}^{1}$ Professor do Programa de Pós-graduação em Educação na Linha de Pesquisa Currículo, Docência e Linguagem da Faculdade de Educação da Universidade Federal do Rio de Janeiro. Jovem Cientista Nosso Estado da FAPERJ. E-mail: <tranniery@yahoo.com.br>

2 Servidor licenciado da Rede Municipal de Educação de Itaboraí. Doutorando em Psicologia na Universidade Federal Fluminense. E-mail: <luancassal@gmail.com>
}

\begin{abstract}
A viral coupling (with HIV) is a composition that tests the mechanisms of temporality of sexual reproduction and social relationality. In this article, we analyze the field that crosses sexuality and degrees of anxiety and panic, exploring the dimensions of contamination within a broader framework of ecological policies. This text is a narrative experiment from trajectories of children living with HIV in schools in which we argue that the imminence of contamination of bodies in the curriculum invites us to think the entanglement between life and death and life and nonlife. Inspired by the debates on biopower, we suggest that the virus is a power figure through which materialisation difference is produced as a metabolic error of the time of reproduction and the projection of the future. Therefore, the experience of these children provides a supplement to the (bio)political considerations of environmental debates. The viral curriculum between sexuality and political ecology that has received little credit in the recent debates on the Anthropocene. These ties complicate the ethical imagination of social life by expanding the body beyond the human. They allow us to address how and where the power arrangements of curriculum can be configured by collapsing bodies as separate and hermetically sealed units.
\end{abstract}

Keywords: children with HIV; biopower; queer ecology; curriculum. 
algum risco, de "virada não-humana"3. Para tanto, explora, de forma tateante, relações entre sexualidade, currículo, discurso ambiental e as políticas de HIV/AIDS na escola. Sua estrutura movente intercruza o percurso de um de nós como psicólogo escolar e suas histórias de escolarização de crianças com HIV/AIDS com a perspectiva explorada pelo outro do currículo como a maquinaria pela qual a escola constitui e distribui a vida e a morte 4 (RANNIERY, 2017). Nesse cruzamento, contaminação é um mecanismo ambivalente de soerguimento de uma barreira de intocabilidade e os acoplamentos virais indicam as dimensões semânticas e materiais, através das quais currículos plasmam, proliferam e incorporam vida e não-vida. O que chamamos de acoplamentos virais possui, por certo, uma valência política, mas também, como iremos sugerir, ecológica e ontológica. Esse terreno de conexões revira históricas de marginalização, pânico e estigma, assim como de criação e reinvenção política e cultural. Essas histórias sobre o HIV serão invocadas nas ficções ${ }^{5}$ que, aqui, trazemos. Em seu pano de fundo, está a sugestão de Despret (2016, p. 2), de que "a ecologia e a cosmologia formam aqui um só e único termo, e sem dúvida deveríamos falar de cosmoecologia que une, assim, destinos interligados dos homens, dos deuses, dos lobos e do gado" - e por que não dos vírus.

O que se segue é um exercício imaginativo de reconstrução e problematização de do pensamento curricular, embaralhando sexualidade e questões ecológicas na tentativa de responder ao profundo silêncio sobre os estudos queer no discurso ambiental (GOUGH; GOUGH, 2011; RUSSEL; SARICK; KENNELY, 2011; MORTIMER-SANDILANDS; ERICKSON, 2010). As histórias que traremos funcionam, para nós, como disparadores, "dados" em um experimento narrativo que nos auxiliam a compor esse texto em resposta "a tarefa de [que] uma teoria curricular comprometida com a alteridade [é] por em questão os seus próprios fundamentos" (MACEDO, 2017, p. 551). Trata-se, pois, de um texto mais especulativo e interrogativo do que resolutivo. Por isso, as seções estão organizadas como camadas entre-cortantes. Elas não explicam umas às outras, não seguem umas às outras. Por sua vez, ecoam histórias proliferantes que se atravessam, se enlaçam, se espraiam, e "não tem como objetivo o estabelecimento de uma narrativa definitiva, mas constitui uma ocasião linguística e social para a autotransformação" (BUTLER, 2015, p.165).

No espírito de Barad (2014), nós configuramos esse texto em torno de uma leitura difrativa - uma figura emaranhada de intersecções, nas quais as seções estão "dispersas, entrelaçadas com efeitos materializadores e sedimentados de reconfigurações iterativas de correspondência espacial, traçados do que ainda pode (ter) aconter(cido)" (BARAD, 2014, p. 196) em contraste com a lógica do conhecimento convergente configurado pelo espelhamento da reflexão. É razoável advertir que não se espere, assim, uma crescente argumentação baseada "na descrição iluminista e humanista do ser humano, da linguagem, do material, do empírico, do real, do conhecimento, do poder, da liberdade e assim por diante" (ST. PIERRE, 2018, p. 1048). Não desejamos interpretar ou analisar as narrativas. Entre elas, "o que existe é muito mais o trabalho de travessia, de prova, de escuta, de exploração tateante de um imenso território desconhecido" (GAGNEBIN, 2009, p.159). O material do cotidiano serve a um "narrador sucateiro", tal como descrito por Gagnebin (2009), que se esmera com os restos e as ruínas do processo normativo, voltando-se "muito mais [para] apanhar tudo aquilo que é deixado de lado como algo que não tem significação, algo que parece não ter nem importância nem sentido, algo com que a história oficial não sabe o que fazer". (GAGNEBIN, 2009, p.54). Em virtude disso, as narrações mudam a cada história, são lançadas "no jogo de um texto que não tem nenhuma leitura finalmente privilegiada nem qualquer história de salvação" (HARAWAY, 2009, p. 89). É um convite a acompanhar diferentes perspectivas e encontros possíveis entre crianças, escolas, vírus HIV e currículos.

\footnotetext{
3 Não nos caberia, aqui, realizar uma genealogia desse movimento, cujo trabalho ainda está por ser feito. Porém, podemos salientar que tal virada inclui movimentos teóricos diversos como teoria do afeto, realismo especulativo, ontologia orientada por objetos, teoria do ator-rede, estudos pós-humanos, estudos animais, crítica ecológica e neomaterialismos.

${ }^{4}$ As pesquisas que subsidiaram esse texto contaram com financiamento da Capes, Cnpq e Faperj.

5 Essas narrativas são exercícios de ficcionalização não porque não são reais ou porque nunca existiram, mas porque problematizam a pretensão de transparência da linguagem a partir da experiência da relacionalidade e da alteridade. Ver, nesse sentido, Ranniery (2018).
} 
Nosso argumento é que uma perspectiva ambiental da educação inspirada na experiência de crianças com HIV não se esgota em denunciar normas de gênero e sexualidade que informam as relações tecidas nos currículos, mas permite recompor currículos como espaços relacionais. Além disso, possibilita abordar a ecologia como um esse complexo entrelaçamento de relações de interdependência que os currículos também compõem. Buscamos, deste modo, ecoar a defesa de Luciano e Chen (2015, p. 18) por uma expansão "do termo queer além de sua ressonância convencional como uma caixa para as não-normatividades sexuais humanas, forçando-nos a perguntar, mais uma vez, o que 'sexo' e 'gênero' podem parecer além das formas antropocêntricas com as quais operamos talvez de forma tão familiar". Esperamos ainda, quem sabe, indicar a necessidade do pensamento curricular apreender os efeitos virais para a vida e a morte e, ao mesmo tempo, que tais reconfigurações são cruciais para qualquer discurso ambiental na educação sensível a degradação do mundo. "Ver a beleza nas feridas e assumir a responsabilidade de cuidar do mundo é o que pretendemos aqui" (MORTIMERSANDILANDS, 2005, s/p). Como Nyong'o (2013) argumentou, um enquadramento queer da política ecológica pode nos permitir descobrir esses mundos dentro nós.

\section{UMA CRIANÇA CAÍDA NO CHÃO}

Quarta-feira pela manhã. Nesta escola pública, é sempre o dia mais cheio e agitado, não se sabe bem o porquê. Alguma combinação entre ausência constante de professores e presença maciça de alunos. Faz sol, mas não está tão quente. Na hora do recreio, uma correria para as poucas inspetoras de disciplina que administram a presença de centenas de crianças do ensino fundamental I e II. As crianças correm para um lado. Os adolescentes organizam-se em grupos para o outro. Às vezes, encontros e cruzamentos, repletos de piadas e desprezo. Lanches, paqueras, gritos, movimentos.

Em meio às agitações e brincadeiras de pique-pega, uma criança da alfabetização cai no chão. Fica estatelada, meio chorosa. Mão e joelho direito estão com alguns arranhões. Coisa leve, mas o susto desorganiza aquele corpo. Algumas continuam a correr, outras ficam em volta, e há aquelas que buscam um adulto.

Uma inspetora logo vê a cena. Aproxima-se rapidamente, tira as outras crianças do entorno da acidentada. Pede que alguma delas chame a coordenação. A que fica no chão começa a chorar. Ninguém a pega, nem a consola. A coordenação e a direção levam os pequenos e grandes para as salas, mesmo antes do horário. Uma espiral de movimento, apenas aquela criança no centro. A criança chora, enquanto a inspetora insiste no isolamento.

A secretaria escolar está um alvoroço. Enquanto uma funcionária liga para a família, outra procura em vão por uma caixa de primeiros socorros. A professora da criança ao chão está próxima, na tentativa de acalmá-la. Ela olha, para de chorar. Encosta no próprio joelho: há um pouco de sangue. Levanta devagar. A inspetora, junto da diretora, afasta os adolescentes; a professora acompanha a criança, a uma distância moderada (segura?).

O que faz um corpo ser impossível de tocar?

\section{CONTAMINAÇÃO!: imunologia e intocabilidade}

Hacer sensible, no sólo "sensibilizar": es decir, traer a modos de la percepción el espacio de relación entre vivos y muertos, que se había vuelto, una vez más, el terreno mismo de lo político. El trabajo sobre ese espaciamiento, siempre indeterminado: los modos materiales, y por lo tanto estéticos (no "estetizados": estéticos, en tanto que organización de lo sensible) por los cuales se inscribe a los muertos en el tejido de la vida, en la comunidad de los vivos. (GIORGI, 2017, p. 250, grifos no original)

2018. A epidemia mundial de HIV/AIDS já avança pela sua quarta década e parece ter chegados aos pátios escolares. A primeira notícia pública data de 1981, no jornal The New York Times, a relatar um raro câncer encontrado em homossexuais, criando o estigma de uma doença associada exclusivamente à homossexuais: câncer ou peste gay (FERREIRA, 2018). Àquela altura, as práticas sexuais dissidentes 
foram associadas à contaminação. Conjugadas aos discursos de estigma e de pânico moral, a lenta resposta dos governos e a rápida infecção de grupos populacionais produziram esvaziamento de espaços de encontro e interação bem como diversos episódios de discriminação e violência contra corpos, assim como aquela criança caída no chão, marcados como capazes de infectar a saúde social, de contaminar a comunidade dos vivos. Como Pereira (2001) percebeu, o que, em muitos casos, a AIDS propiciou, em especial quando ligada a aparatos institucionais, foi um favorecimento à ruptura de vínculos. Patton (2002) notou ainda que os legados conjugados do colonialismo e da modernidade permitiram uma espetacular e insidiosa reciclagem de ideias racistas, sexistas, xenófobas e homofóbicas como se fossem científicas em torno das políticas de combate ao HIV/AIDS. Na "epidemia de significação" (TREICHLER, 1987) que os discursos políticos e científicos proliferavam, o diagnóstico certeiro de Perlongher (1987, p. 66) nos é instigante, "o interesse que o show da subinformação satisfazia nas massas tinha algo de dileção mórbida. [...] sob a desculpa da AIDS, as liberdades cotidianas, os direitos de ir e vir são cerceados".

Porém, e se décadas depois, nem tudo em torno da criança caída no chão do pátio escolar for sobre o romance da segregação social? Mais do que as práticas sexuais ou de sujeitos perigosos e imorais, cindidos e apartados, histórias como essa nos auxiliam a descrever os acoplamentos virais como emaranhados através dos quais tramas curriculares abduzem um corpo intocável quando se é forçado a manter trocas e relações. Como efeito, diante do sangue com HIV escorrendo de um joelho em um recreio escolar, somos levados a pensar não sobre cisão de domínios de legitimidade, mas sobre laços de relacionalidade. A queda, que abre o corpo ao mundo, torna possível reconhecer que estamos ligados aos outros e, mais ainda, situar os acoplamentos virais no contexto do trabalho de vidas e mundos, se não além, ao menos não exclusivamente, humanos. A pergunta, o que faz um corpo impossível de tocar?, pode ser, assim, explorada em sua ambiguidade. É uma interrogação ambígua porque, o vírus, tal como Chen (2011) descreveu sobre as toxinas, ao ter uma reconhecida capacidade de envenenar corpos tomados como animados - os corpos infantis que brincam no recreio, - desfazendo sua especificidade morfológica - nesse caso, o furor saudável do moderno imaginário pedagógico sobre as crianças - alcançam sua própria animação como um agente que pode prejudicar a qualquer um.

Se, como Haraway (1993) registrou a articulação semiótica-material consiste em práticas de junção e construção de alianças e conexões, a contaminação que leva todas as outras crianças para dentro das salas de aula e o corpo caído ao isolamento intocável, é uma composição de uma rede inextricável de relações, "articulando uma entidade social coletiva entre humanos, outros organismos e outros tipos de atores não-humanos" (HARAWAY, 1993, p. 310). Os acoplamentos virais podem ser, deste modo, tomados como arranjos técnico-naturais que nos voltam às formas de materialização corporal da diferença promulgadas através dos currículos "sempre conjugadas com atenções para afetar-se, enredar-se e romper-se” (HUSTAK; MEYERS, 2012, p. 106). Nessa direção, acoplamentos virais não conformam uma identidade; não são simplesmente uma categoria, um designador social ou um nome para algum tipo de subjetividade. Antes, indicam um encontro perigoso que acontece no currículo à medida que formações de poder se reconfiguram. Isso porque esses arranjos nunca são inocentes; conformam-se "sobre a estruturação mútua e geralmente desigual" (HARAWAY, 1993, p. 2018) cultivada por meio de "práticas contestáveis [nas quais] os parceiros nunca são colocados de uma vez por todas" (HARAWAY, 2008, p. 314). Aquilo que Hustak e Meyers (2012) nomearam de ecologia afetiva das relações não está menos sujeita à contaminação desses laços por ser aberta a parceiros imprevisíveis e, por vezes, perigosos.

Logo, o soerguimento da barreira de intocabilidade é uma resposta a essa vulnerabilidade compartilhada e a imprevisibilidade que os laços de convivência do currículo expõem. Não foi, pois, sem razão que Perlongher (1987, p. 10) tenha notado que "uma doença relacionada com o sexual toca num ponto particularmente sensível para a sociedade contemporânea, tão preocupada com a higiene e o cuidado do corpo". E, décadas depois, não é surpreendente que uma doença deslocada, agora, para a contaminação do sangue toque no ponto sensível da gestão de fluídos que os currículos promovem. Higiene e cuidado conformaram, de fato, muito dos modelos de prevenção à AIDS que inundaram as políticas de sexualidade na década de 1990. Como bem mostrou Donini (2003), suas poderosas fantasias buscaram, com força, evitar o contato com o outro, fortalecer-se na experiência individualizada e 
reduzir os riscos de contaminação. A forma dessa contenção é, de fato, invenção de desse outro exteriorizado - aquele com o qual não se pode interagir corporalmente -; a "persistente constituição do Outro como sombra do Eu" (SPIVAK, 2010, p. 46). Todavia, a emergência da intocabilidade não leva na escola, como poderia parecer à primeira vista, a um encapsulamento total. Por outra via, aponta para uma disseminação progressiva, pois só é possível na proliferação de cenas cotidianas de contato, ou ao menos de ameaça dele, nas brigas, nas brincadeiras, nos abraços e beijos e no fluídos que carregam.

Podemos creditar tal espraiamento à "qualidade sinestésica da sensação materializada" (HAYWARD, 2010, p. 580) dos acoplamentos virais funcionar de forma correlata a posturas emocionais marcadas por pavor, medo e angústia. Tais estados afetivos acionam e constituem um conjunto de sentimentos que são, por sua vez, alegorias desse outro alterizado (NGAl, 2007) e erguem a cerca da contaminação e sua ambivalente barreira de intocabilidade. Estamos insistindo no adjetivo ambivalente porque nem a intocabilidade nem a contaminação elevam-se sobre um corpo preexistente. Estão, ao mesmo tempo, dentro e fora do corpo - nas conexões internas entre vírus HIV e sangue e, ao mesmo tempo, nas conexões entre corpo infantil e espaço escolar, quando a barreira se rompe. A intocabilidade é um mecanismo performativo, no sentido de tornar visível a AIDS na escola como sinônimo de alguém possuidor de algo fora de controle. Para tanto, a intocabilidade enlaça-se à diferença, indicando mais uma "separabilidade agencial, de exterioridade-dentro" (BARAD, 2012, p. 32) do que uma separação absoluta.

Haraway (1989), certa vez, argumentou que os sistemas imunológicos estão fortemente entrelaçados com as marcações biopolíticas entre "nós" e "eles". A própria noção medicalizada de imunidade é derivada de ancoragens políticas em que "o discurso do sistema imunológico é sobre as chances desigualmente distribuídas de vida e morte" (HARAWAY, 1993, p. 322). Por sua vez, Chen (2011) sugeriu que os embates sobre a contaminação - dentre os quais podemos situar as reações ao contato com crianças com HIV na escola - invocam a imunidade ameaçada da comunidade como condição para a sua emergência. Sua inspiração é o argumento de Esposito (2017) de que a imunidade está entrelaçada com a comunidade, trazendo à cena um enfraquecimento da possibilidade final da imunidade prometida. Tal promessa só é possível de ser realizada no interior de uma ecologia social interdependente dos corpos. Embora essa interdependência possa gerar desejos de maior proteção, a instável introjeção do agente negativo no interior da própria comunidade é a forma da comunidade de se defender. O efeito é conhecido: a impureza, a sujeira, a desordem ou a abjeção não podem ser eliminadas de uma vez por todas e para sempre muito menos serem hermeticamente isoladas. Sobrevivem com força; assombram porque nos constituem.

A barreira intocável não é bem-sucedida por seu soerguimento depender de um desfazer constante do corpo como unidade individual. De tal modo, os acoplamentos virais reconfiguram o corpo das crianças com HIV/AIDS em um curto-circuito da figura do corpo biológico imune, inteiriço e íntegro, aquele "o corpo humano como uma coisa orgânica discreta" (PUAR, 2013, p. 357) a ser preservado e protegido pela escola. A criança com HIV na escola torna-se intocável ao fazer emergir, como que em uma fresta, ligações entre sistemas imunológicos, sangues, cápsulas virais, sexualidade, tecnologias, corpos infantis, professores, famílias. A intocabilidade é, de fato, a fantasia aterradora de conter a instável interconstituição que qualquer currículo faz opera. Os projetos educacionais com sua teleologia evolutiva buscam, entretanto, suturar a dimensão imprevisível dessa relacionalidade. Diante das crianças como proeminentes recipientes de vida e de futuro para o discurso pedagógico corrente (LAJONQUIÈRE, 1999), a jogo da contaminação nos força a pensar tanto sobre vida e morte quanto sobre a reprodutividade do futuro e, em virtude de enlaçar tais questões, coloca uma política ecológica.

Se pudermos ir além dos dolorosos efeitos antissociais, tomando os momentos nos quais o sangue escorre pelo joelho, entre o soluço e o choro, temos uma oportunidade de abordar os laços que currículos tecem, agora, de outra entrada, a partir das "vidas sociais queer-inanimadas que existem além do fetiche, além do animado, além do puro choque do sexo humano" (CHEN, 2011, p. 282). Podemos colocar outras perguntas: o que acontece ao currículo quando a contaminação adentra na fisicalidade ou, se quisermos escrever com Povinelli (2006), a carnalidade das relações que se tecem nos 
currículos? Isto é, o que acontece aos currículos quando os corpos carregam, em uma paráfrase de Butler (2002), a contaminação como parte do seu próprio sangue? Ou ainda, quando arranjos não são apenas inter-relacionais, mas, nos termos de Barad (2007), são, simultaneamente, intra-espécies (humanos e vírus) e intra-materiais (sangue e vírus)? O que é, afinal, o corpo aqui? E se o corpo tiver substancialmente alterado pela contaminação? Não seria, pois, o vírus uma figura coextensiva da biopolítica que avança o dispositivo da sexualidade para além dele mesmo e o recoloca como parte de um diagrama mais amplo de governo da existência?

\section{Um futuro}

Os ânimos são sempre exaltados no curso pré-vestibular. Os filhos da elite da cidade querem entrar nos cursos mais concorridos da universidade pública - especialmente medicina e engenharia. Nas conversas de corredor e lanchonete, os alunos se queixavam dos sistemas de reserva de vagas que dificultavam seu acesso e tornavam a disputa desigual e injusta. Os exames simulados produzem listas de classificação, com premiações internas. Os melhores lugares em sala são disputados. Os adolescentes e jovens sabem que não há vaga para todo mundo.

Ela sempre senta nos primeiros lugares. Fica bastante concentrada nas aulas. Mesmo assim, é mais conhecida por sua gargalhada alta e sonora, quando os professores fazem piadas ou músicas que ajudam na memorização. Aquele riso que contagia e deixa com vontade de rir também.

Alguns colegas estranharam quando ela estava mais quieta na aula. Mas acontece, tinham muito conteúdo para se concentrar. E era comum terem dias sofridos com toda aquela pressão. Ficou assim durante a terça, a quarta, faltou na quinta e na sexta... O que poderia ter acontecido?

Não houve nada de diferente no cotidiano da semana. Nas aulas de segunda-feira, discutiram bioética e reprodução. A apresentação alegre e dinâmica envolveu questões sobre fertilização in vitro, eugenia através do aperfeiçoamento genético, uso de preservativos, reprodução assistida. A bateria de exercícios colocava em jogo quem - e como - pode reproduzir. Condições diferenciadas que pudessem ser transmitidas deveriam ser prevenidas? Alguns procedimentos deveriam ser obrigatórios? Que pessoas e situações implicam uso compulsório de preservativos, por que, para quem?

É noite. Ela está em casa enquanto os outros estão na aula. Na escrivaninha, tenta repassar os conteúdos. O corpo dela foi tornado objeto de estudo. Deveria falar, ou seguir em silêncio? Diz à família que está passando mal e não consegue ir às aulas nesses dias. Estuda em casa. O cursinho é muito bom, mas não consegue estar lá. O que significa assumir uma posição? Vão desconfiar dela? Como manter seu segredo, o que vão pensar? A ideia de sua vida foi tratada como menos - não deve reproduzir, ou o poderia apenas excepcionalmente, em laboratórios. Estava exposta e, ao mesmo tempo, em sigilo. Nem sabe se quer ter filhos; por enquanto, só deseja uma vaga na universidade. Mas já se sente presa, pelo olhar, pela fala, por um projeto que se impõe.

Já está tarde. Interrompe tudo, marca os livros e os papéis. Vai em busca do lanche, dos remédios da noite, da pausa para o sono e o sonho. Amanhã, decidirá o que fazer.

\section{Um vírus, uma criança}

Questões sobre a vida e a morte e, logo, sobre o futuro, que acompanham a jovem estudante têm sustentado os diversos ativismos - incluindo a pesquisa e a teorização acadêmica - em torno do HIV/AIDS. Vários movimentos sociais se organizaram, no Brasil e no exterior, de forma a afirmar a importância de manutenção das vidas e de lamentar as inúmeras mortes por consequência da lenta resposta do poder público, o direito às práticas e prazeres sexuais, bem como a posição estratégica da indústria farmacêutica de produção de lucro (com estudos e tratamentos) a partir do adoecimento (PERLONGHER, 1987; CRIMP, 2002). Esse foi um capítulo conflituoso na configuração do processo descrito por Pelúcio (2009) de sidanização. Hoje, ao final da segunda década do século XXI, a emergência da AIDS reconfigurou a paisagem do dispositivo da sexualidade (CARRARA, 2015). Mais do que nunca, de lá para cá, o HIV se tornou "um nexo onde múltiplos significados, histórias e discursos se cruzam e se sobrepõem, reforçam e subvertem uns aos outros" (TREICHLER, 1987, p. 42). A ampliação do cuidado e da promoção em saúde aumentou as possibilidades de vida e, com isso, trouxe novas questões, ainda pouco exploradas no debate curricular sobre "a história desses corpos cujos destinos 
se teceram na encruzilhada de um vírus e uma política" (GIORGI, 2017, p. 252). Essas são histórias cujos planos de existência, entre remédios e ausências, arrastam essa encruzilhada de viver entre um vírus e uma política para a relacionalidade que o currículo tece.

As possibilidades de escolarização da jovem estudante são efeitos de políticas articuladoras de suporte para a vida e da disputa pública de responsabilidade para com as mortes. Na década de 1990, crianças que estavam "contaminadas" desde o nascimento atingiram a idade escolar - e, evidentemente, seu ingresso nas instituições educacionais não aconteceu de forma tranquila. $O$ pavor da contaminação e o consequente segredo ou isolamento de quem vivia com HIV/AIDS colocou uma série de tensões para as escolas. De acordo com a ABIA (1993), diversos jornais acompanharam a situação de crianças com HIV com matrículas recusadas em escolas da rede pública do município de São Paulo em 1992. Não foram os primeiros casos, mas a recusa ganhou enorme visibilidade e possibilidade de disputa pública. Foram ainda necessárias ações judiciais e manifestações de movimentos sociais, como da própria organização, que é especializada na atenção às pessoas vivendo com HIV/AIDS. Em resposta às violações, os Ministérios da Saúde e da Educação lançaram a Portaria Interministerial 796 de 1993 visando garantir o direito à educação. O documento prevê a estudantes e trabalhadores o direito ao sigilo; a não obrigatoriedade de informação sobre estado sorológico; e a proibição de divulgação em caso de ciência, de compulsoriedade de exames ou de segregação dessas pessoas. A decisão de informação sobre a condição sorológica ficaria a critério dos sujeitos.

Essa formulação é, entretanto, evocadora da conhecida da transparência da figura do sujeito. Trata-se de uma das pressuposições ontológicas modernas que, nota Silva (2007), introduz a universalidade da razão como um descritor jurídico, criando, no mesmo passo, uma cena de regulação nas quais os corpos são nomeados como capazes de autoconhecimento e "ao nomeá-los, intelectuais representam a si mesmos como transparentes" (SPIVAK, 2010, p. 37). A emergência dessa figura conhecedora de si está enredada no dispositivo da sexualidade, como a leitura de Foucault (1988) não deixou passar incólume. O sujeito jurídico depende vastamente de um lastro, no qual é formulado como uma figura externa às ferramentas da universalidade da razão que, por sua vez, produz e regula as condições através das quais diferentes tipos de seres humanos são nomeados: "o sujeito autodeterminado e os seus outros exteriormente determinados cujas mentes [e corpos] estão sujeitas (no sentido científico) às condições naturais" (SILVA, 2007, p. 7). Esse estatuto de sujeito só é possível quando é performado por meio de uma integridade corporal, o que quer dizer, materializado através do mecanismo ambivalente da imunidade à "natureza". Entretanto, cair no chão ou faltar à aula enquanto se sonha o futuro plasmariam os corpos infantis com HIV/AIDS como depoimentos de mais suscetíveis à "natureza" ou equiparáveis a ela, tanto por sua disponibilidade para manejo, quanto por, sempre, conterem em seu sangue algo sobre qual se pode perder o controle.

O enlace crianças, na escola, vivendo com HIV/AIDS discorre sobre condições através das quais se perde a decisão de falar sobre a condição sorológica. Ela é sempre anunciada a fim de proteger a comunidade. Tal anúncio não é apenas revelador de um segredo. Sua propagação, como condição da imunidade, torce a integridade corporal do sujeito jurídico como forma de introjeção desse outro corporalmente intocável. O decreto da condição sorológica opera, portanto, como um regulador ontológico. A integridade corporal é também uma tecnologia de regulação ao apagar a "vida molecular" (MEYERS, 2015) dos acoplamentos virais, a fisicalidade dos elementos que viajam dentro, sobre e através de nós, e às vezes permanecem em nós, incrustados na carne, nas vísceras, nas células e no sangue. Por um lado, a miragem do sujeito como projeto a ser construído pelo currículo perde de vista como mecanismos de poder produzem corpos, agora, "como informação, como matéria [...] não predominantemente por meio da significação, mas mediante tendências afetivas" (PUAR, 2013, p. 366). Por outro, o nó está na associação dessa materialidade à "natureza", um suposto espaço de reificação e posse, estabilizável e domável, ou, na crítica de Barad (2010), da natureza como essência pura. Essa redução da "natureza" a determinação invariável e apropriação incontestável, erguida através da distinção da cultura, "tornou-se a marca do humano e a marca da civilização" (LUGONES, 2014, p. 936). Essa é uma distinção devedora, lembra Lugones (2014, p. 946), de "uma compreensão esquizoide de 
realidade que dicotomiza humano de natureza, humano de não-humano, impondo assim uma ontologia e uma cosmologia".

Nessa cosmologia, as crianças e jovens que vivem com HIV/AIDS na escola são reinseridas em um registro de uma "natureza" incontrolável, contaminante, aterradora e monstruosa. O acoplamento viral é, pois, um aparato biopolítico e um arranjo ontológico, um emaranhado ao mesmo tempo sexual e ecológico. Tanto a agenda ambiental - com seu projeto de conservação que aparta o humano - quanto a agenda das políticas sexuais - com seu pressuposto que de que tudo é construção e, por efeito, espelho do humano - são gêmeas tributárias dessa uma natureza amorfa, passiva e disponível. De um modo ou de outro, ambas são curto-circuitadas pela relacionalidade que os acoplamentos virais acionam diante e dentro de nós, ou ainda, de que "vivemos com outros corpos dentro de nós, micróbios e bactérias; estamos em meio a forças, afetos, energias; somos compostos de informação" (PUAR, 2013, p. 357). De fato, nossa sugestão é que a "criança que privamos de qualquer força de resistência, de qualquer possibilidade de fazer um uso livre e coletivo do seu corpo, de seus órgãos e seus fluídos sexuais" (PRECIADO, 2013, p. 96) exige mesmo alguma reinvenção do pensamento curricular sensível às políticas ecológicas em sentido mais aberto. Sedgwick (1991) já alertava para como as fantasias alimentadas pela AIDS poderiam fazer desaparecer a força propulsora da política queer diante da ausência de discursos que nutrissem as experiências de crianças queers. Nós estamos sugerindo que uma das formas de alimentar tal florescimento é corroer a distinção entre o biológico e geofísico que, há séculos, tem servido de passagem para o trator desenvolvimentista da cosmologia moderna.

Muita embora as separações - humano e natureza, natureza e cultura, por exemplo, - pareçam ser mesmo o coração da teoria curricular, as histórias das crianças com HIV nas escolas não são univocamente ou facilmente humanistas, e esta qualidade permite uma reconstrução inumana da maquinaria curricular. Queerizar - uma designação provisória - o currículo depende, quem sabe, de nos voltarmos agora "para a natureza como se fosse para a terra, para o material primordial - o geotrópico, o fisiotrópico. [...] nós viajamos para a terra, um lugar comum" (HARAWAY, 1993, p. 296). Uma indicação desse porte pode soar estapafúrdia dada à sensação que noções como "natureza" e "biologia" provocam, não sem razão, entre os estudos de gênero, sexualidade e currículo. Nós não estamos, entretanto, defendendo um retorno à "natureza". Estamos destacando que recolocar a relacionalidade que o currículo tece implica ir além da excepcional agência humana individualizada. Estamos ainda indicando a urgente necessidade de reativar os corpos das crianças com HIV como parte de um mundo compartilhado. Um mundo no qual fomos lançados no meio de contínuo emaranhado entre humanos e não-humanos em seus atravessamentos e conexões, em tornar-se com, nos termos de Haraway (2008), composto por camadas múltiplas de naturezasculturas, para usar outra expressão da autora, que constituem as possibilidades de viver e morrer.

\section{Tempo de vida, tempo de morte}

Quando nos aproximamos dessa geração de crianças vivendo com HIV/AIDS na escola, é possível realizar que "'uma vida', então, é sempre uma multiplicidade aberta que adquire uma nova visibilidade onde o biológico e o vivo se tornam o protagonista político" (GIORGI, 2017, p. 254). O enlace das histórias que trouxemos a esse texto, percorrendo sexualidade e políticas de HIV/AIDS, nos permite afirmar que currículo é um dos terrenos em que esse encontro entre o biológico e o vivente ganha protagonismo político. Mais propriamente, é um encontro regulado em torno da aquilo que Mirzoeff (2016a) nomeou de complexo de visualidade, com suas técnicas de classificar, separar e estetizar. Visualidade e anúncio são mesmo partes do pouco segredo que se faz em torno das práticas sexuais - e, no caso das crianças com HIV, com a sorologia -, como explicou Foucault (1988) desde a emergência do dispositivo da sexualidade, com sua multiplicação de saberes, discursos e práticas a compor uma estratégia potente e perversa de controle dos corpos, subjetividades e populações. Potente porque o poder avança cada vez mais fundo sobre os modos de existência; perversa porque provoca a existência de formas de produção não para exterminá-las totalmente, mas, sim, para a instituição de uma ordem regulada de funcionamento das vidas.

Essa estratégia é sobre "um poder cuja função mais elevada já não é mais matar, mas investir sobre a vida, de cima a baixo" (FOUCAULT, 1988, p. 152). É um poder sobre a vida através de duas 
políticas que se entrecruzam: uma primeira que toma o corpo como máquina, uma "anatomo-política do corpo humano" (FOUCAULT, 1988, p. 151, grifo do autor); a segunda trata do corpo como espécie. Em resumo, "a biopolítica vai se dirigir [...] aos acontecimentos aleatórios que ocorrem numa população considerada em sua duração" (FOUCAULT, 1999, p. 292-293). Não é difícil derivar que, no nível da anatomia política, currículos invistam na produção do corpo das crianças com HIV/AIDS por meio de um exercício minucioso de verificação e acompanhamento, em observações constantes dos contatos que as crianças estabelecem na escola com outras crianças. No nível da população, os corpos são alvo de gestão das relações, que visam evitar a propagação do vírus horizontal e verticalmente. O dispositivo da sexualidade torna-se um operador do tempo da vida (e da morte), articulando corpo-indivíduo e corpopopulação. Dito de outro modo, reprodução e segurança ou, nos termos de Edelman (2008), esse futuro reprodutivo implacável, apontam que o que está "no cerne deste problema econômico e político da população: [é] o sexo" (FOUCAULT, 1988, p. 32). Garante-se, pois, que as crianças vivam com HIV/AIDS, ao mesmo tempo em que se criam mecanismos para que não haja transmissão.

O corpo das crianças com HIV torna-se uma espécie de catalisador por meio do qual não somente a imunidade biológica da comunidade é constituída como ameaçada, mas o futuro (re)produtivo de toda a sociedade está em jogo. Temporalidade e sexualidade se encontram, assim, por meio de "um modo de implantação, uma técnica através da qual forças institucionais são percebidas como fatos somáticos. [...] formas da experiência temporal que parecem naturais para aqueles aos quais elas privilegiam" (FREEMAN, 2010, p. 3). Como Puar (2007) aponta, as economias biopolíticas segregam sujeitos do reino privilegiado da vida otimizada ao empurrá-los para o domínio da morte - se não, física, ao menos, social. Por isso, nossa insistência em afirmar que acoplamentos virais não dão a ver a contenção projetada sobre o corpo das crianças e seu gerenciamento, mas funcionam como um vórtice das condições afetivas, materiais e relacionais através das quais vida e morte são suportadas. Nosso ponto reside em indicar que, no coração do currículo, podemos colocar um projeto similar ao conclamado por Mbembe (2018), aquele de considerar categorias mais terra-a-terra, menos reflexos da abstração humanista do discurso educacional, categorias tais como a vida e a morte.

O diagrama necropolítico exortado por Mbembe (2018) liga morte e terror à temporalidade política, a "formas únicas e novas de existência social, nas quais vastas populações são submetidas a condições de vida que lhes conferem ao estatuto de "mortos-vivos"' (MBEMBE, 2018, p. 71). Todavia, quando a contaminação parece ser constitutiva do próprio viver dos corpos infantis com HIV, o acoplamento viral bagunça, em uma torção, a distinção entre vida e morte. Aqui, a mortalidade é aquilo através da qual alguém vive - não apenas a possibilidade de morrer, mas de ameaçar com a morte que Ihe é constitutiva, todos os outros. Se a mortalidade - ou a possibilidade de matar por contaminação está contida na própria possibilidade de viver, o "corpo contaminado" não é mais um corpo vivo, tampouco é um corpo que está morto. Se, o vírus está contido no corpo, de modo que esse corpo não é mais íntegro, se os emaranhados de relações são invisíveis, ou visíveis apenas via decreto da contaminação, o corpo contaminado é transformado em uma arma. Entretanto, o sentido, aqui, não é balístico, como no terrorista de Mbembe (2018), é biológico, ao deslocar pares como animado/inanimado, exterior/interior, segurança/risco, indivíduo/sociedade, corpo/sujeito e vida/morte.

A essa altura, finalmente, podemos retornar a estranheza de dispor um ensaio em torno da HIV/AIDS na escola em um dossiê sobre o discurso ambiental e currículo. A própria ideia de celebrar quatro décadas de institucionalização da agenda ambiental e seus impactos no pensamento curricular pode apontar para a problematização que desejamos lançar. A visão ambientalista, aquela caracterizada por Carvalho (2001) da invenção do sujeito ecológico e da sensibilidade que o acompanha, embora apoie a extensão progressiva do debate ambiental a populações antes não reconhecidas, não critica, entretanto, a composição sexual da política ambiental. Dito de outro modo, por vezes, a temporalidade (re)produtiva, âncora da moderna ficção da natureza como objeto passivo, inanimado, sinônimo de essencialização, é também dependente do dispositivo da sexualidade. Em resumo, aos marcos da ontologia naturalista moderna sustentam não apenas tudo aquilo que o discurso ambiental buscou criticar, mas também as políticas sexualidade com suas pretensões de desnaturalizar. De uma só vez, as 
histórias das crianças com HIV na escola transformam os limites entre matéria e vida biológica.

Nós gostaríamos de situar essa conexão sobre o que significa essas histórias no contexto do Antropoceno, perguntando se as contaminações virais de uma geração de corpos que já vivem com HIV também não encenam algo da intrusão de Gaia, usando a bela expressão de Stengers (2015). Cunhado para descrever uma nova época geológica na qual o planeta passa a exibir as marcas do impacto da ação humana sobre sua superfície (LEWIS; MASLIN, 2015), Antropoceno ganhou alguma popularidade, ainda que pouco usado no campo curricular brasileiro, ao conectar a crença do domínio humano da natureza com o capitalismo e a conformação de um mundo que se considera feito de um mundo unificado e único (LAW, 2011). Um sobrevoo superficial da literatura sobre o Antropoceno não tardará a constatar que, no anúncio da falência do sistema de coordenadas moderno emerge uma interrogação sobre os domínios da natureza, passiva, por definição e pressuposto e, como corolário, da cultura como seu suplemento (KIRBY, 2011). Trata-se de uma aposta sobre como as reconfigurações ecológicas estão levando ao "fim da velha distinção humanista entre história natural e história humana" (CHAKRABARTY, 2013, p. 91). Para nós, a história do HIV, revolvida e emaranhada nas narrativas que cortam nosso texto, vem documentando, nos corpos de uma geração de crianças, essa reconfiguração.

São histórias que desafiam o pensamento curricular a conectar sexualidade e ecologia, ligando a interrogação sobre a destituição de formas de vidas com a uniformização do mundo e sua degradação. Se, como Mirzoeff (2016b) sugeriu, raça é um nexo significativo do legado colonial do Antropoceno, que escreve e inscreve a coisificação da natureza como disponível à apropriação, não é despropositado indicar, mesmo que discretamente, sua conexão com o dispositivo da sexualidade. Povinelli (2016a) sugere, por exemplo, que o vírus é mesmo uma das figuras contemporâneas do dispositivo da sexualidade no Antropoceno ao "configura[r] o conhecimento de é que o ser humano, e a própria vida" (POVINELLI, 2012, p. 17). O que está em dispersão na escala globalizada é um esquema ontológico regulador no qual se dá a emergência do "ser vivo e, mais especificamente, [do] ser que extrai sua diferença da diferença absoluta entre seres vivos e não-vivos" (POVINELLI, 2016, p. 17). Dito de outro modo, a ontologia performada entre nós é, nos termos da autora, uma bio-ontologia, isto é, um conjunto de discursos, afetos e táticas que mantêm e moldam a relação da distinção entre vida e nãovida. Esse cerceamento busca caracterizar a existência de qualidades e capacidades metabólicas, como nascimento e reprodução, como associadas à vida (POVINELLI, 2017). Conformações bio-ontológicas são, assim, dependentes de uma diferença entre o animado e o inerte e o efeito dessa demarcação é a separação supostamente incondicional e invariável entre o orgânico e inorgânico.

Não se trata mais apenas de fazer viver e fazer morrer, mas, para seguir Povinelli (2016a), criar e manter a divisão entre vida e não-vida como crucial para a transformação da materialidade em objeto passível de apropriação. Nos acoplamentos virais, não está em curso apenas o embate entre vida e morte, mas entre a vitalidade e a esterilidade; entre vidas a serem contaminadas e que podem morrer e as vidas já infectadas; entre quem tem futuro e quem já não pode mais tê-lo. Esses mecanismos ajustam e modulam corpos através da permeação material ao invés constituir sujeitos discretos legíveis contra um padrão de humanidade. São corpos sendo empurrados para "uma forma de morte que começa e termina em não-vida" (POVINELLI, 2016b, s/p). Em outras palavras, os corpos de crianças com HIV permanecem no conjunto da vida apenas na medida em que se pode manter a distinção entre morte (para todo alvo da contaminação) e não-vida (para quem a contaminação já é uma condição de viver). $O$ fio que conecta as duas faces de nosso percurso indica que as presunções bio-ontológicas sobre "vida" e "natureza" agem como uma divisão fundacional através dos qual os currículos materializam corpos "contaminados", empurrando-os para um campo suspenso entre a morte e a não-vida, "uma terceira zona, entre o estatuto de sujeito e objeto" (MBEMBE, 2018, p. 39). As crianças com HIV nas escolas abrem os arranjos através dos quais "nós" e "eles", quer que sejam uns e outros, não simplesmente nascemos, reproduzimos e morremos.

Diante daquilo que Freeman (2010) nomeou de crononormatividade, um nome com o qual podemos indicar que o tempo do progresso desenvolvimentista é também o tempo reprodutivo da heterossexualidade como regime político, esses corpos estão sendo (des)feitos em práticas de tempos emaranhados, nas quais o futuro não é mais um garantia. É sobre o signo dessa incerteza que não desejamos roubar a carteira política que a contaminação pode conter ao envolver "as superfícies 
ordenadas e todos os planos com os quais estamos acostumados a domar a profusão selvagem das coisas existentes [...] e ameaçar com o colapso nossa antiga distinção entre o Mesmo e o Outro" (FOUCAULT, 1970, p. 15). Nessas histórias, corpos são materializados sem que se possa tomar por dada a distinção entre humano e não-humano e mesmo entre natureza e cultura. A estranheza em torno do que um currículo produz, como, certa vez, exortou Silva (2006), desloca-se, aqui, para o que está sendo engajado no momento em as relações estão em curso. A pesquisa em currículo, presa a uma ontologia dualista é desafiada, não por modismo ou vontade deliberada, mas porque as formas de poder por meio das quais currículos materializam corpos estão alterando o tempo da vida e o tempo da morte.

Em síntese, o excepcionalismo humano é um "arcabouço ultrapassado para construir uma teoria que esteja disposta a explicar as questões de abjeção e a construção diferencial do humano, quando as gradações da humanidade, incluindo a desumanização, são frequentemente constituídas em relação aos não-humanos" (BARAD, 2012, p. 30). Para nós, acoplamentos virais trazem à torna uma rede em que pessoas, vírus, arquiteturas escolares, exames médicos, ações oficiais estão sendo em emaranhados com efeitos cruciais sobre a vivibilidade dos corpos. Esses efeitos sinalizam para como o currículo está mais para um enredamento espaço-temporal materializante, fazendo dos corpos, "em suas emaranhadas manifestações físicas e psíquicas, [...] sempre uma colcha de retalhos, uma sutura de partes díspares" (BARAD, 2015, p 393). Com isso, os acoplamentos virais desfazem a fantasia de exterioridade radical como definidora da experiência queer no currículo. As implicações políticoecológicas dessas histórias giram torno de manter alguma resistência em assumir que o "corpo contaminado" seja inerentemente inadequado no passo de insistir na ecologia com um movimento de composição de relações de interpendência. $O$ que tais corpos trazem à tona é como relações específicas de diferenciação promulgadas pelos currículos não apagam, ainda que busquem, que a "alteridade é uma relação emaranhada de diferença" (BARAD, 2012, p. 47). Sua face monstruosa emerge do emaranhamento dos próprios "acoplamentos perversos e promíscuos" (BARAD, 2015, p. 412) aos quais os currículos nos sujeitam. A "forma informe, muda, infante e terrificante da monstruosidade" (DERRIDA, 1991, p. 197) é constitutiva da própria relacionalidade que um currículo produz.

\section{Uma briga}

O casal chega com pressa na escola. Passa pelo portão, pela cantina, pelo corredor principal. Chega à sala da direção. Fala com a funcionária e é rapidamente atendido pela diretora e o coordenador. O menino está lá, e parece bem, exceto pela cara emburrada. Trocam cumprimentos rápidos e sentam nos lugares indicados.

A diretora explica a situação - o aluno brigou com outro colega, também do ensino médio, na hora da saída. O coordenador detalha que o colega estava provocando-o, o menino partiu para a agressão - e agora ele interrompe, perguntando se deveria deixar por isso mesmo quando zoam com ele.

A diretora levanta a voz, ali não é lugar para gritar. Os pais pedem para que ele fique em silêncio. A mãe pergunta sobre o outro menino e sua família. O coordenador conta que o rapaz foi advertido por escrito e dispensado, e a família virá em outro momento. Chamaram-nos imediatamente porque ficam preocupados com a situação do menino. Ele precisa entender que seu caso é especial, e não pode se machucar, entrando em brigas. Afirma, ainda, que felizmente nada de mais grave aconteceu e a própria turma rapidamente separou os alunos. Não comentaram o assunto com os colegas, mas precisam pensar em como garantir uma permanência de qualidade e segurança.

Na semana seguinte, a família decide pela mudança de escola.

\section{TODO ENSAIO TEM SEU FIM}

A briga, a mudança de escola, a queda no pátio, as faltas no cursinho apresentam elementos de afastamento e segregação das três histórias que cruzamos e revolvem múltiplos tempos e percursos através dos quais a vida e a morte são distribuídas. Essas vidas são mesmo sobre "a história médica, do tempo do vírus, dos processos biológicos e imunológicos, dos contágios e imunizações, e do olhar sobre 
populações e agenciamentos entre formas humanas e não-humanas" (GIORGI, 2017, p. 253-254). O que chamamos de acoplamentos virais não se reduzem, deste modo, a um corpo sujeito humano, posto que "são tempos em que o bios que não coincide com as formas dadas do eu" (GIORGI, 2017, p. 253-254). Essa reconfiguração do bios desmonta a fantasia da imunidade comunitária e conforma 'erros' metabólicos do tempo do nascimento e da reprodução por meio dos quais as tramas curriculares plasmam corpos contaminados em um espaço suspendido e intervalar entre a morte e a não-vida. Essas histórias são sobre a complexidade de um aparato de poder em transformação através do qual os currículos dão forma à existência e sobre como estão envolvidos no modo pelo qual corpos são constituídos "na relacionalidade: implicados, obrigados, derivados, sustentados por um mundo social além de nós e anterior a nós" (BUTLER, 2015, p. 87) - um mundo que também está, agora, dentro de nós, (des)fazendo esse nós, nos transformando.

É essa rede, cuja energia ontologizante faz com que a "história dos seres vivos não se pareça mais com uma árvore em que cada ramo se separa dos outros de forma clara e definitiva, mas, antes, uma rede estreita de laços que tecem relações constantes, e que remodelam os seres nessas relações" (DESPRET, 2016, p. 26) que estamos chamando de currículo. Manter, hoje, a força do discurso ambiental no pensamento curricular tem exige cruzar distintas agendas políticas a fim de reconhecer o que acontece quando uma figura de poder remodela corpos e relações para longe de uma noção fixa e universal de natureza. Este é também um compromisso com a impossibilidade do pensamento curricular subsumir quaisquer arranjos relacionais a uma simples analítica das categorias de classificação. Nesses quarenta anos do discurso ambiental, a tarefa que defendemos por uma teoria curricular sensível à degradação do mundo implica em estar atenta à rede material e incorpórea que nos despossui, de que "estamos todos em nossa própria pele, entregues nas mãos dos outros, à mercê dos outros” (BUTLER, 2015, p.131). Essa rede permanece não somente no ar, no significado da cultura ou na marca subjetiva, mas se incrusta na carne, corre através dela, como uma espécie de um rumor contaminante em constante de dispersão. Esta é um imperativo ético que a alteridade nos exige e que os estudos queers há muito têm exortado na educação.

Talvez o que os estudos queers tragam para o discurso ambiental seja uma renovação imaginativa em como abordar a tessitura de arranjos entre humano e inumano, natureza e cultura. Esse trabalho de ecologia queer implica repensar a experiência tanto da teoria e dos conceitos correntes que conformam os estudos queers quanto do pensamento curricular. É um investimento sintonizado "com as condensações do passado e do futuro [..]; que implica superposições de muitos seres e tempos, múltiplas im/possibilidades que coexistem; [...] explorações materiais das indeterminações mútuas do ser e do tempo" (BARAD, 2015, p. 388). Para um campo como do currículo que sempre esteve atado a um humanismo pululante, pode ser um passo incrivelmente difícil de ser dado. Contudo, parece ser essa a lição queer - se é que podemos escrever nesses termos - que as histórias dos corpos com HIV nos desafiam a levar a sério ao cruzarem, de forma inapropriada, política sexual e política ecológica. Essa ligação elétrica que as histórias de crianças com HIV na escola trazem entre ecologia queer e discurso ambiental indica como o currículo participa do entalhamento da existência nesse nosso mundo em ruínas - um mundo no qual, como Caio Fernando de Abreu (2016, p. 82) bem descreveu, "alguma coisa explodiu, partida em cacos. A partir de então, tudo ficou ainda mais complicado. E mais real". Em um conto de título sugestivo, Transformações, tais narrativas deixam em aberto se conseguiremos transformar nossos conceitos para responder as transformações ecopolíticas que explodiram aquilo que somos e nos tornaram mais reais.

\section{REFERÊNCIAS}

ABIA. A AIDS e a escola. Rio de Janeiro: ABIA, 1993.

ABREU, Caio Fernando. Morangos mofados. Rio de Janeiro: Nova Fronteira, 2016.

BARAD, Karen. Meeting the Universe Halfway. Durham: Duke University Press, 2007.

BARAD, Karen. Nature's Queer Performativity. Kvinder, Køn \& Forskning, n. 1-2, p. 25-53, 2012.

BARAD, Karen. Diffracting Diffraction: Cutting Together-Apart. Parallax, v. 20, n. 3, p. 168-187, 2014. 
BARAD, Karen. Transmaterialities: Trans*/matter/realities and Queer Political Imaginings. Gay and Lesbian Quartely, v. 21, n. 2-3, p. 387-422, 2015.

BUTLER, Judith. Relatar a si mesmo. Belo Horizonte: Autêntica, 2015.

BUTLER, Judith. Como os corpos se tornam matéria. Revista Estudos Feministas, v. 10, n.1, p. 155-167, 2002.

CARRARA, Sergio. Moralidades, racionalidades e políticas sexuais no Brasil contemporâneo. Mana, v. 21, p. 323-345, 2015.

CARVALHO, Isabel Cristina de Moura. A invenção do sujeito ecológico: sentidos e trajetórias da educação ambiental. Tese (Doutorado em Educação). Universidade Federal do Rio Grande do Sul, Porto Alegre, 2001.

CHAKRABARTY, Dipesh. O clima da história: quatro teses. Sopro, v. 91. 2013.

CHEN, Mel. Toxic Animacies, Inanimate Affections. GLQ: A Journal of Lesbian and Gay Studies, v. 17, n.23, p. 265-286, 2011.

CRIMP, Douglas. Melancholia and moralism: essays on AIDS and queer politics. Massachusets: MIT Press, 2002.

DESPRET, Vicienne. O que os animais diriam se...?. Cadernos de Leitura, n. 45, maio 2016.

DERRIDA, Jacque. Escritura e diferença. São Paulo: Perspectiva, 1991.

DONINI, Ângela. Potência virótica da vida: afeto, escrita e subjetivação. Dissertação (Mestrado em Psicologia). Pontifícia Universidade Católica de São Paulo, São Paulo, 2003.

EDELMAN, Lee. No Future. Durham: Duke University Press, 2008.

FERREIRA, João. Primeiras ficções sobre o VIH/sida: Buddies, An Early Frost e Parting Glances. In: CASCAIS, António Fernando; FERREIRA, João. 0 vírus-cinema: cinema queer e VIH/sida. Lisboa: Associação Cultural Janela Indiscreta, 2018, p. 14-23.

FOUCAULT, Michel. The order of things. New York: Vintage Books, 1970.

FOUCAULT, Michel. História da Sexualidade I. Rio de Janeiro: Graal, 1988.

FOUCAULT, Michel. Em defesa da sociedade. Rio de Janeiro: Martins Fontes, 1999.

FREEMAN, Elizabeth. Time Binds. Durham: Duke University Press, 2010.

GAGNEBIN, Jeanne-Marie. Lembrar escrever esquecer. São Paulo: Editora 34, 2009.

GIORGI, Gabriel. Política de la supervivincia. Kamchatka: Revista de Análisis Cultural, n.10, 2017, p. 249260.

GOUGH, Noel; GOUGH, Anette. Contos de Camp Wilde: tornando queer a pesquisa em Educação Ambiental Ambiental. Estudos Feministas, v. 19, n. 1, 312, p. 239-263, jan-abr/2011.

HARAWAY, Donna. Staying with the Trouble. Durham: Duke University Press, 2016.

HARAWAY, Donna. When Species Meet. Minneapolis: University of Minnesota Press, 2008.

HARAWAY, Donna. O Manifesto Ciborgue. In: SILVA, Tomaz Tadeu (Org.). Antropologia ciborgue: as vertigens do pós-humano. $2^{\mathrm{a} e d .}$ Belo Horizonte, Autêntica, 2009. p. 33-118.

HARAWAY, Donna. The Promises of Monsters: A Regenerative Politics for Inappropriate/d Others In: GROSSBERG, Lawrence; NELSON, Cary.; TREICHLER, Paula. (eds). Cultural Studies New York; Routledge, 1993. p. 295-337.

HARAWAY, Donna. The Biopolitics of Postmodern Bodies: Determinations of Self in Immune System Discourse. diferences, v. 1, n. 1, p. 3-43, 1989. 
HAYWARD, Eva. Fingeryeyes: Impressions of Cup Corals. Cultural Anthropology, n. 25, v. 4, p. 577-599, 2010.

HUSTAK, Carla; MYERS, Natasha. Involutionary Momentum: Affective Ecologies and the Sciences of Plant/Insect Encounters. Différences, v. 23, n. 3, p. 74-118, 2012.

KIRBY, Vicky. Quantum antropologies. Durham: Duke University Press, 2011.

LAW, John. What's Wrong with a One-World World. Paper apresentado ao Center for the Humanities, Wesleyan University, Connecticut em 19 de Setembro de 2011. Disponível em: http://www.heterogeneities.net/publications/Law2011WhatsWrongWithAOneWorldWorld.pdf Acesso em: 14 de março de 2018.

LEWIS, Simon; MASLIN, Mark. Defining the Anthropocene. Nature, v. 519, n. 12, 2015.

LAJONQUIÈRE, Leandro. Infância e ilusão (psico)pedagógica. São Paulo: Vozes, 1999.

LUGONES, Maria. Rumo a um feminismo decolonial. Estudos Feministas, v. 22, n.3, p. 935-952, set-dez 2014 .

LUCIANO, Dona. CHEN, Mel. Has the Queer Ever Been Human?. Gay and Lesbian Quartely, v. 21, n. 2 - 3, p. 183-207, 2015.

MACEDO, Elizabeth. Mas a escola não tem que ensinar?: Conhecimento, reconhecimento e alteridade na teoria do currículo. Currículo sem Fronteiras, v. 17, n. 3, p. 539-554, set./dez. 2017.

MORTIMER-SANDILANDS, Catriona. Unnatural Passions?: Notes Toward a Queer Ecology, Invisible Culture. An Electronic Journal for Visual Culture, v. 9, 2005. Disponível em: http://www.rochester.edu/in_visible_culture/lssue_9/titleg.html. Acesso em: 2 de junho de 2018.

MORTIMER-SANDILANDS, Catriona. ERICKSON, Bruce. A Genealogy of Queer Ecologies. In: ERICKSON, Bruce. Queer Ecologies. Bloomington: Indiana University Press, 2010. p. 1-47.

MBEMBE, Acquille. Necropolítica. São Paulo: n-1 Edições, 2018.

MIRZOEFF, Nicholas. O direito de olhar. Educação Temática Digital, v.18 n.4 p.745-768 out./dez. 2016 a.

MIRZOEFF, Nicholas. Não é o Antropoceno, é a cena da supremacia branca ou a linha divisória geológica da cor. Baula, 2016b. Disponível em: http://www.buala.org/pt/a-ler/nao-e-o-antropoceno-e-acena-da-supremacia-branca-ou-a-linha-divisoria-geologica-da-cor. Acesso em: 5 de maio de 2018.

MEYERS, Natasha. Rendering Life Molecular. Durham: Duke University Press, 2015.

NGAI, Sianne. Ugly Feelings. Cambridge: Harvard University Press, 2005.

NYONG'O, Tavia. Back to the Garden: Queer Ecology in Samuel Delany's Heavenly Breakfast. American Literary History, v. 24, n. 4, 2013. 747-767.

PATTON, Cindy. Globalizating AIDS. Minneapolis: University of Minnesota Press, 2002.

PELUCIO, Larissa. Abjeção e Desejo. São Paulo: Annablume, 2009.

PEREIRA, Pedro Paulo. Sucatas do mundo: noções de contaminação e de abjeção em uma instituição de portadores de Aids. Sociedade e Cultura, v. 4, n. 2, p. 127-147,jul./dez. 2001.

PERLONGHER, Néstor. O que é AIDS. São Paulo: Brasiliense, 1987.

PRECIADO, Paul B. Quem defende a criança queer?. Jangada, n. 1, p. 96-99, jan-jun 2013.

POVINELLI, Elizabeth. The Empire of Love. Durham: Duke University Press, 2006

POVINELLI, Elizabeth. Geontologies. Durham: Duke University Press, 2016a.

POVINELLI, Elizabeth. Geontologies: The Figures and the Tactics. e-flux, n. 78, 2016b. Disponível em: https://www.e-flux.com/journal/78/81514/geontologies-the-figures-and-the-tactics/. Acesso em: 2 de junho de 2018. 
POVINELLI, Elizabeth. Interview with Elizabeth Povinelli by Mat Coleman and Kathryn Yusoff. Theory, Culture \& Society. Volume Especial, p. 1-17, 2017.

PUAR, Jasbir. Terrorist Assemblages. Durham: Duke University Press, 2007.

PUAR, Jasbir. "Prefiro ser um ciborgue a ser uma deusa": interseccionalidade, agenciamento e política afetiva. Meritum, v. 8, n. 2, p. 343-370, jul./dez. 2013.

RANNIERY, Thiago. Currículo, normatividade e políticas de reconhecimento a partir de trajetórias escolares de 'meninos gays'. Education Policy Analysis Archives, v. 25, p. 1-32, 2017.

RANNIERY, Thiago. Vem cá, e se fosse ficção?. Práxis Educativa, v. 13, p. 982-1002, 2018.

RUSSEL, Constance; SARICIK, Tema; KENNELY, Jackie. Tornando queer a educação ambiental. Estudos Feministas, v. 19, n. 1, 312, p. 239-263, p. 225-239,jan-abr/2011.

SEDGWICK, Eve. How to Bring Your Kids Up Gay. Social Text, v. 29, p. 18-27, 1991.

SILVA, Denise. Toward a Global Idea of Race. Minneapolis: University of Minnesota Press, 2007.

SILVA, Tomaz Tadeu. $\mathbf{O}$ currículo como fetiche. Belo Horizonte: Autêntica, 2006.

SPIVAK, Gayatri. Pode o subalterno falar?. Belo Horizonte: Editora da UFMG, 2010.

SPOSITO, Roberto. Bios: biopolítica e filosofia. Belo Horizonte: Editora da UFMG, 2017.

STENGERS, Isabelle. No tempo das catástrofes. São Paulo: Cosac \& Naify, 2015.

ST. PIERRE, Elizabeth. Uma história breve e pessoal da pesquisa pós-qualitativa: em direção à "pósinvestigação". Práxis Educativa, v. 13, n. 3, p. 1044-1064, set./dez. 2018.

TREICHLER, Paula. AIDS, Homophobia, and Biomedical Discourse: An Epidemic of Signification. October, v. 43, p. 31-70, 1987.

Recebido em: 21/06/2018

Alterações recebidas em: 17/10/2018

Aceito em: 09/11/2018 